\title{
APPLICATION OF THE DOUBLE SKIN FACADE CONCEPT IN AN EFFORT TO INCREASE THE THERMAL COMFORT OF IMAGE STUDIO ROOM
}

\author{
Johar Maknun ${ }^{1}$, Tjahyani Busono², Iday Hidayat ${ }^{3}$ \\ 1,2 Department of Architectural Engineering Education, Universitas Pendidikan Indonesia, Bandung \\ City, Indonesia. \\ 3 Alumni of Architectural Engineering Education Study Program, Universitas Pendidikan Indonesia, \\ Bandung City, Indonesia. \\ Corresponding author: joharmaknun@upi.edu; tiahyanibusono@upi.edu; idayh4241@gmail.com
}

$\begin{array}{crrr}\text { Received: } 20 \text { April } & \text { Revised: } 26 \text { April } & \text { Article History: } & \\ 2020 & 2020 & \text { Accepted: } 28 \text { April } & \text { Available online: } 30 \text { April } \\ 2020 & 2020 & 2020\end{array}$

\begin{abstract}
The development of technology in buildings is one of the factors triggering the acceleration of methods in the facade configuration system. Double Skin Facade (DSF) is one of the building facade concept innovations. The purpose of applying the DSF concept is to optimize the use of energy-related to the air conditioning system to obtain thermal comfort in buildings. The results of measurements of the existing condition of the Image Studio room in the morning until 11.00 are included in the optimal comfort category, $11.00-13.00$ are in the warm comfortable category, and starting at 13.00-18.00 tend not to meet thermal comfort. Based on the simulation results the use of Double Skin Facade can reduce the temperature in the room around $3.47^{\circ} \mathrm{C}$. With the application of Double Skin Facade in this Image Studio room, it can reduce the heat radiation from sunlight that directly enters through the window because it can be detained first in the double facade. The application of the Double Skin Facade can increase the thermal comfort of an Image Studio room.
\end{abstract}

Keywords: Double Skin Façade, Thermal Comfort

\section{Introduction}

The lecture hall where the teaching and learning process takes place requires a design that can adapt to climate conditions. Geographically, Indonesia is located at $60 \mathrm{LU}$ to 110 south latitude, this causes Indonesia to be classified into a humid tropical climate, with high intensity of solar radiation, relatively high air temperature, high humidity and rainfall, and always cloudy sky conditions (Lippsmeier, 1997).

The issue of energy conservation is currently widely used, especially with the use of passive systems. This has to do with issues of comfort and economics. One of the goals in designing buildings is to save energy without having to sacrifice comfort needs for the occupants (Lechner, 2007). The relationship between buildings, comfort, and energy is a building capable of modifying unwanted outdoor climate (uncomfortable) into a climate inside a building that is comfortable for residents (Sugini, 2004).

Environmental conditioning in the building can be carried out architecturally by considering the placement of buildings (the orientation of buildings to the sun and wind), the use of architectural and landscape elements, and the use of building materials following the character of the humid tropical climate (Kragh, 2000). Through environmental conditioning in buildings, the temperature in the room can be reduced by a few degrees without the aid of mechanical equipment. Heat enters the building through the conduction process (through walls, roofs, glass windows) and solar radiation that is transmitted through windows/glass (Talarosha, 2005). 
The development of technology in buildings is one of the factors triggering the acceleration of methods in the facade configuration system. Double facade or known as Double Skin Facade (DSF) is one of the innovations of the building facade concept. The purpose of applying the concept of a double facade (DSF) is to strive to optimize the use of energy to reduce the cooling load of buildings, especially about air conditioning systems to obtain thermal comfort in buildings (Zanghirela, et. al., 2010).

Double Facade is defined as the building envelope which has two ordinary single facade layers on the inside and a second glass layer on the outside. In general, each of these layers is known as building skin (Loncour et. al., 2004). Double Skin Facades is a facade system in a building consisting of two layers of glass skin which are placed in such a way that there is airflow in the cavity located in the middle between the two layers. The cavity between the two building shells forms a space that functions as a ventilation system through the utilization of natural airflow. The ventilation cavity has dimensions of $20 \mathrm{~cm}-200 \mathrm{~cm}$ (Poirazis and Rosenfeld, 2004).

Claessens and De Herde (Poirazis and Rosenfeld, 2004) stated that the Double Skin Facade is an additional building envelope mounted on the existing facade and is usually transparent. The new space between the second skin and the original facade is a buffer zone that serves to protect the building. This space also functions as a protector from the heat emitted by solar radiation. For south-oriented systems, solar hot air is used for winter heating in subtropical climates. In the summer period, the facade must be re-adjusted to prevent overheating in other periods.

Double Skin Facade is a jacket construction consisting of two transparent surfaces separated by a cavity, used as an air duct (Saelens and Hends, 2001). The use of active systems in a double facade can reduce thermal conduction on the inner glass, thereby increasing thermal comfort in the room. In a study, it has been concluded that Double Skin Façade which works actively shows better performance compared to the passive system (Loncour et. al., 2004). This study aims to find the potential application of the Double Skin Façade concept as a form of building response to local climatic conditions, to produce an adaptive form of the application of a double facade in buildings that can improve the thermal comfort of spaces in buildings.

\section{Research Methods}

The research method used is Research and Development (R\&D), which is the process of developing a new product or perfecting an existing product, which can be accounted for (Sukmadinata, 2005). The product referred to in this study is an architectural product in the form of the design to perfect the design of the facade of the building of Image Studio Room of the Department of Architectural Engineering Education, Faculty of Technology and Vocational Education, Indonesia University of Education. The design is based on the Double Skin Facade concept to enhance thermal comfort.

The research location is in the city of Bandung, West Java Province, Indonesia. The object of research is the Image Studio room of the Department of Architectural Engineering Education, Faculty of Technology and Vocational Education, Indonesia University of Education. Bandung City is located between 1070 East Longitude and 6055 'South Latitude. Topographically the city of Bandung is located at an altitude of 768 meters above sea level, the highest point in the North with an altitude of 1,050 meters, and the lowest in the South is 675 meters above sea level (Soegijanto, 1999). 


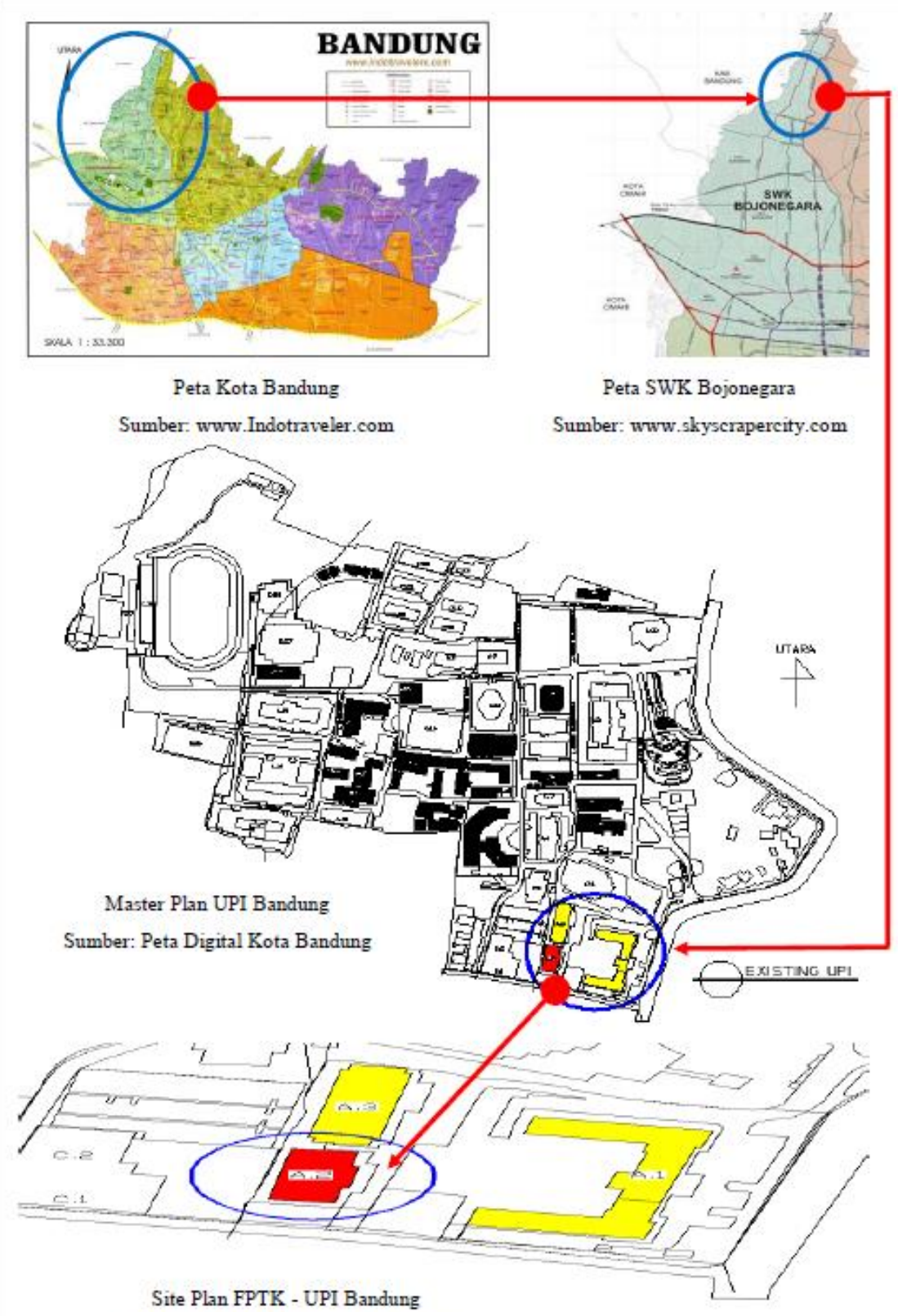

Figure 1 Research Location, 2015, Photo, and Drawing. Source: Authors

Data filtering is used to measure the existing physical and environmental conditions of the study site. Measurements made are as follows:

a. Measurement of the geometry of the room and aperture on the wall

b. Listing of wall, aperture, floor and ceiling material

c. Measurement of air temperature

d. Measurement of wind speed

e. Measurement of relative humidity

Data processing of the results of this study was carried out as follows:

a. Use descriptive statistics to find a general picture of the quality of the physical environment of the Image Studio room, the quality of the building, the level of thermal comfort, and natural lighting in the lecture room.

b. The simulation uses Autodesk Ecotect Analysis 2011 by making a building model of the Faculty of Technology and Vocational Education, Indonesia University of Education. 


\section{Result and Discussion}

\subsection{Existing Condition of Studio Image Room}

Data description of the Image Studio Room, Department of Architectural Engineering Education, Faculty of Technology, and Vocational Education, Indonesia University of Education is shown in the following table.

Tabel 1. Data Description of Image Studio Room

\begin{tabular}{ll}
\hline - Room Name & Image Studio \\
\hline - Room Length & $12.00 \mathrm{~m}$ \\
\hline - Room Width & $9.00 \mathrm{~m}$ \\
\hline - Room Height & $2.30 \mathrm{~m}$ \\
\hline - Room Area & $108 \mathrm{~m}^{2}$ \\
\hline - Aperture: & \\
- Window type $1 \times 1$ unit & $4.25 \times 1.50=6.37 \mathrm{~m}^{2}$ \\
- Window type $2 \times 1$ unit & $2.85 \times 1.50=4.27 \mathrm{~m}^{2}$ \\
- Window type $3 \times 3$ unit & $1.80 \times 1.90=3.42 \mathrm{~m}^{2}>10.26 \mathrm{~m}^{2}$ \\
- Window type $4 \times 8$ unit & $1.90 \times 0.90=1,71 \mathrm{~m}^{2}>13.63 \mathrm{~m}^{2}$ \\
- Door & $2.70 \times 1.70=4.59 \mathrm{~m}^{2}$ \\
\hline - Material : & \\
- Floor & Plain ceramic $40 \times 40 \mathrm{~cm}$ \\
- Wall & The masonry walls, \\
- Ceiling & Wooden frame poly board partition \\
- Jamb & Gypsum board \\
- Window Coverings & Aluminum \\
\hline
\end{tabular}

Orientation Space Studio Image facing East and West. So that direct sunlight enters the room with high sunlight intensity and disturbs the user in the room. The building is well oriented NorthSouth, the light received by the building is the bright light of the sky.

The location of this Image Studio room is in the West. so that in the afternoon, when the sun is in the west the light directly enters the room. The room becomes uncomfortable to use because the effect that the room has added is to get hotter and the room user feels dazzled by direct sunlight.

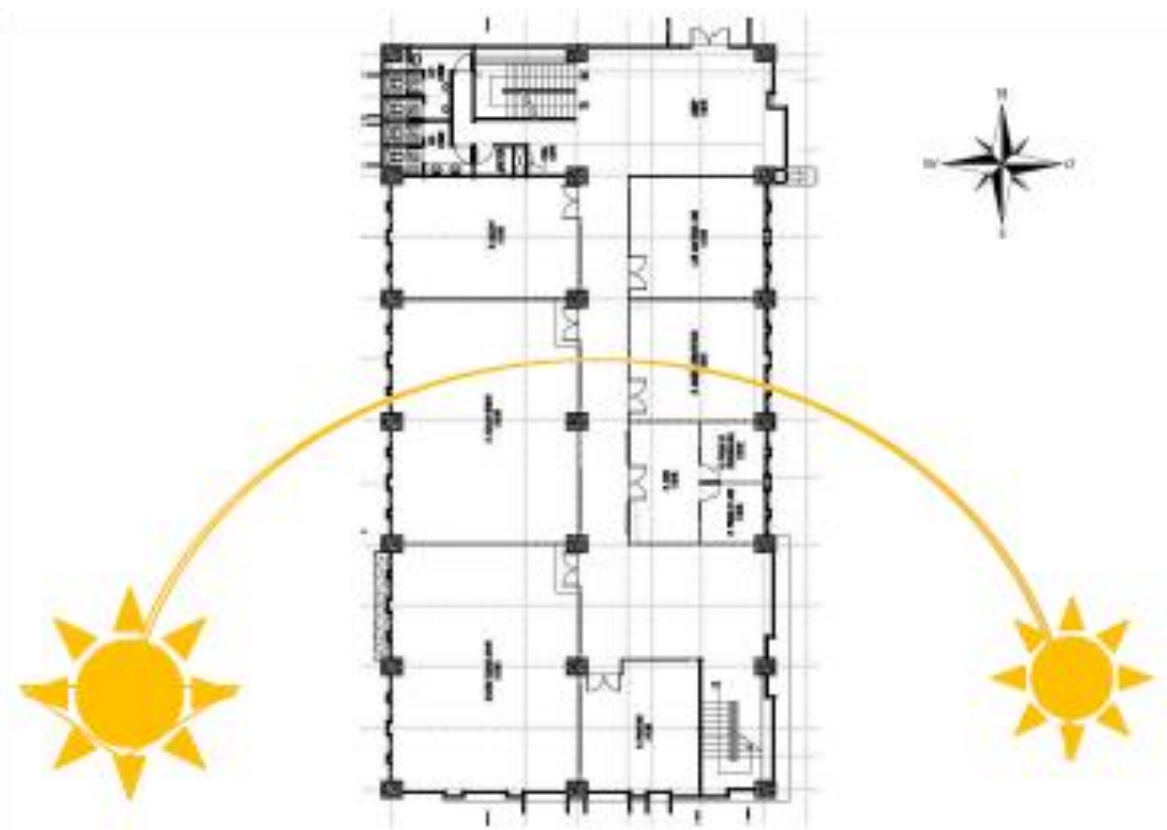

Figure 2. The orientation of Sunlight Against the Room, 2015, Drawing. Source: Authors 


\subsection{Condition of Thermal Comfort of Studio Image Room}

According to SNI T-14-1993-03, the procedures for designing energy conservation in buildings, thermal comfort areas for Indonesians can be divided into:

a. Cool comfortable, between the effective temperature of $20,5^{\circ} \mathrm{C}-22,8{ }^{\circ} \mathrm{C}$

b. Optimal comfort, between the effective temperatures $22,8^{\circ} \mathrm{C}-25,8^{\circ} \mathrm{C}$

c. Warm comfortable, between the effective temperatures $25,8{ }^{\circ} \mathrm{C}-27,1{ }^{\circ} \mathrm{C}$

The temperature measurement results are shown in Figure $3(a)$ and the humidity listed in Figure 3 (b). While the wind speed ranges from $0-0.5 \mathrm{~m} / \mathrm{s}$.
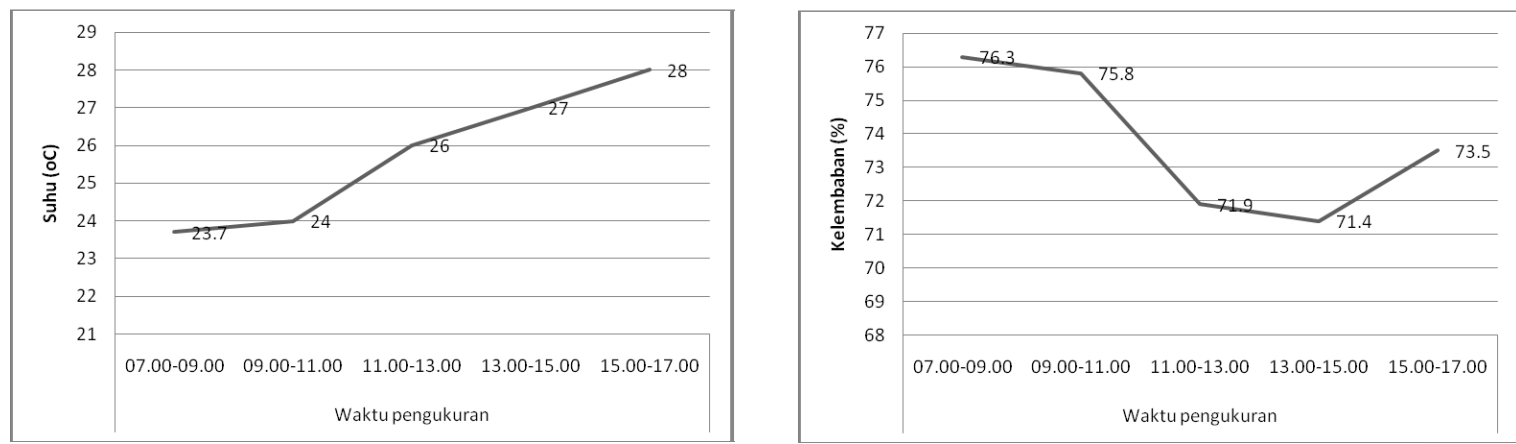

Figure 3 (a) Temperature Measurement Results (left) and (b) Moisture Measurement Results (right), 2015,

Measurement.

Source: Authors

On the west side, the window is in the form of awnings with one window each, having a size of $2.10 \mathrm{~m} \times 0.80 \mathrm{~m}$, totaling 8 windows. From this window, solar radiation can enter directly into the Image Studio room. While on the east side, the window used is a fixed window type, this window faces the corridor in the building so that this window does not provide direct solar radiation. This is consistent with the results of temperature measurements in the morning $23.7^{\circ} \mathrm{C}$ and continues to increase until the afternoon which is equal to $28^{\circ} \mathrm{C}$. While the relative humidity in the morning is higher at $76.3 \%$ and tends to decrease towards noon.

Based on these data, in the morning until 11.00, it is included in the optimal comfort category and starts at $11.00-13.00$, including the warm comfortable category. While starting at 13:00 tend not to meet thermal comfort. The analysis of the results of the study concluded that the thermal comfort of a building is greatly influenced by the movement of the sun.

From the data shown in Figure 3, the processing is done using Autodesk Ecotect Analysis 2011. Data from the simulation of Image Studio Room using the Autodesk Ecotect Analysis 2011 software is shown in Figure 4.

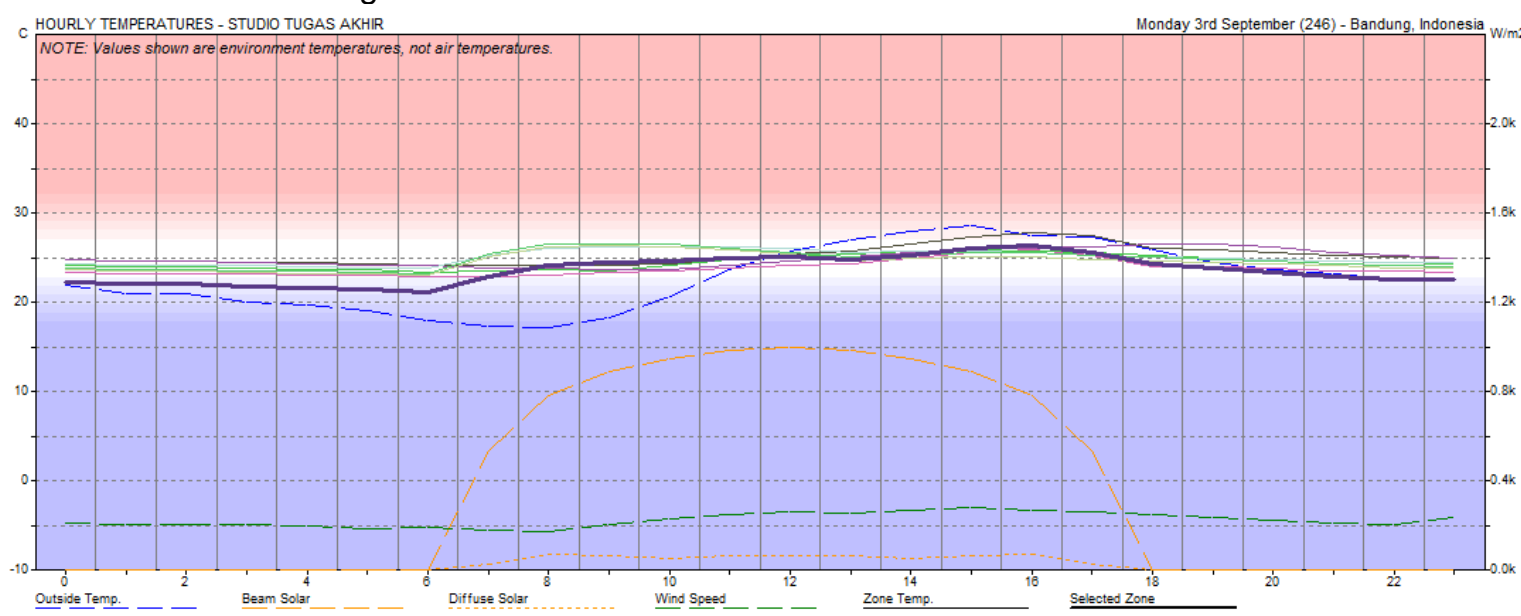

Figure 4. Daily Temperature Conditions Image Studio Room, 2015, Measurement.

Source: Authors

This simulation result data has the same pattern as the measurement results in the field, even though the temperature conditions are lower than the direct measurement results data. The reason for the lower temperature difference in the simulation results is because it is difficult to make a simulation that matches the real conditions. Daily Temperature Studio Images processed by the Autodesk Ecotect Analysis 2011 software are listed in Table 2. 
Tabel 2. Daily Temperature of Final Project Studio

\begin{tabular}{cccc}
\hline HOUR & INSIDE & OUTSIDE & TEMP.DIF \\
\cline { 2 - 4 } & (C) & (C) & (C) \\
\hline $\mathbf{0 0 . 0 0}$ & 23.4 & 22.0 & 1.4 \\
\hline $\mathbf{0 1 . 0 0}$ & 23.1 & 21.0 & 2.1 \\
\hline $\mathbf{0 2 . 0 0}$ & 23.1 & 21.0 & 2.1 \\
\hline $\mathbf{0 3 . 0 0}$ & 22.9 & 20.1 & 2.8 \\
\hline $\mathbf{0 4 . 0 0}$ & 22.7 & 19.7 & 3.0 \\
\hline $\mathbf{0 5 . 0 0}$ & 22.6 & 19.2 & 3.4 \\
\hline $\mathbf{0 6 . 0 0}$ & 22.3 & 18.0 & 4.3 \\
\hline $\mathbf{0 7 . 0 0}$ & 24.4 & 17.4 & 7.0 \\
\hline $\mathbf{0 8 . 0 0}$ & 25.4 & 17.2 & 8.2 \\
\hline $\mathbf{0 9 . 0 0}$ & 25.6 & 18.4 & 7.2 \\
\hline $\mathbf{1 0 . 0 0}$ & 25.7 & 20.7 & 5.0 \\
\hline $\mathbf{1 1 . 0 0}$ & 25.7 & 23.7 & 2.0 \\
\hline $\mathbf{1 2 . 0 0}$ & 25.2 & 25.8 & -0.6 \\
\hline $\mathbf{1 3 . 0 0}$ & 25.0 & 27.0 & -2.0 \\
\hline $\mathbf{1 4 . 0 0}$ & 25.9 & 28.0 & -2.1 \\
\hline $\mathbf{1 5 . 0 0}$ & 27.1 & 28.6 & -1.5 \\
\hline $\mathbf{1 6 . 0 0}$ & 27.0 & 27.5 & -0.5 \\
\hline $\mathbf{1 7 . 0 0}$ & 26.6 & 27.4 & -0.8 \\
\hline $\mathbf{1 8 . 0 0}$ & 24.9 & 26.0 & -1.1 \\
\hline $\mathbf{1 9 . 0 0}$ & 24.6 & 24.6 & -0.0 \\
\hline $\mathbf{2 0 . 0 0}$ & 24.3 & 23.7 & 0.6 \\
\hline $\mathbf{2 1 . 0 0}$ & 23.9 & 23.2 & 0.7 \\
\hline $\mathbf{2 2 . 0 0}$ & 23.6 & 22.6 & 1.0 \\
\hline $\mathbf{2 3 . 0 0}$ & 23.5 & 22.5 & 1.0 \\
\hline & & & \\
\hline & & & \\
\hline
\end{tabular}

In table 2 it can be seen that the minus result at the diffuse temperature (difference) is an indicator that the room is uncomfortable, as indicated in red in the table above. This uncomfortable temperature condition is because the temperature in the room is almost close to the air temperature outside the room. The uncomfortable temperature on the simulation results is at $12.00-18.00 \mathrm{WIB}$. While the comfortable temperature conditions are at 18:00 to 11:00 WIB, and the average temperature in the room is $22.7^{\circ} \mathrm{C}$.

In Figure 4 you can see the room temperature of the Image Studio room at the time of measurement. This daily temperature is made to see at what time the room is comfortable and uncomfortable. In the picture that can be seen as a graph of the increase in temperature in the room, the green line in the picture shows the temperature begins to increase in the range of 07.00 , the average temperature is above $25^{\circ} \mathrm{C}$. the temperature is increasing and experiencing a peak at $13: 00$ until 17:00 WIB. From $15: 00$ to $16: 00$ the air temperature in the room is at an uncomfortable temperature point based on the SK SNI 03-6572-2001 standard which is at a temperature of $27.1^{\circ} \mathrm{C}$. As for the wind speed in the room marked with a green dotted line in the range of $0.2 \mathrm{~m} / \mathrm{s}$ (Satwiko, 2005).

\subsection{Impact of the Application of the Double Skin Facade Concept on Thermal Comfort}

To control climate factors to obtain thermal comfort in buildings, the easiest way with a mechanical approach is to use an Air Conditioner (AC) but requires no small operational costs. The second approach is to condition the environment inside the building naturally with an architectural approach (Cheol, 2003). 
To reduce heat radiation and glare from the sun one of which can be done by filtering to soften the sun's rays, especially during the day so that solar heat radiation is minimized so that comfort in the room associated with room temperature becomes more balanced and not too dazzling (Sukawi, 2010). To overcome the problem of thermal comfort, researchers propose an alternative, namely the application of the concept of Double Skin Facade (DSF).

The room that will be installed by the Double Skin Facade is the Image Studio room on the third floor of the Faculty of Technology and Vocational Education building of the Indonesia University of Education. This is because the existing room on the third floor experiences the highest sun exposure. While the first floor and second floor can still be obstructed by trees around the building. The results of the Double Skin Facade design in the Image Studio Room The images are in Figure 5 and the Double Skin Façade details are shown in Figure 6.

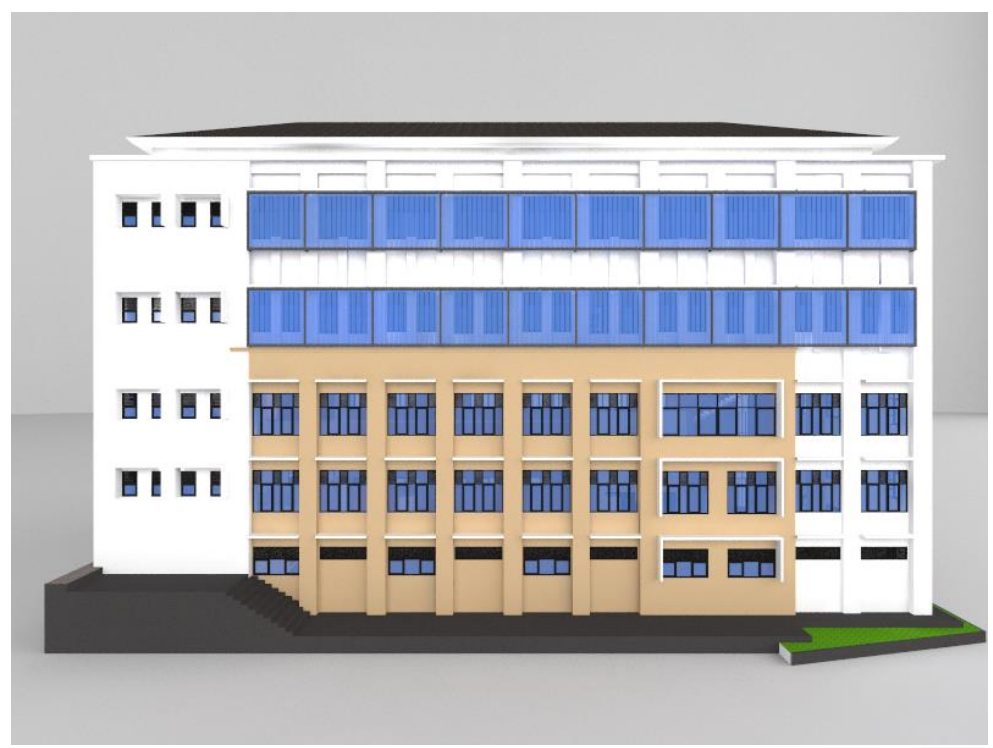

Figure 5. Western Looks of the Application of Double Skin Facade in Image Studio, 2015, Drawing Source: Authors
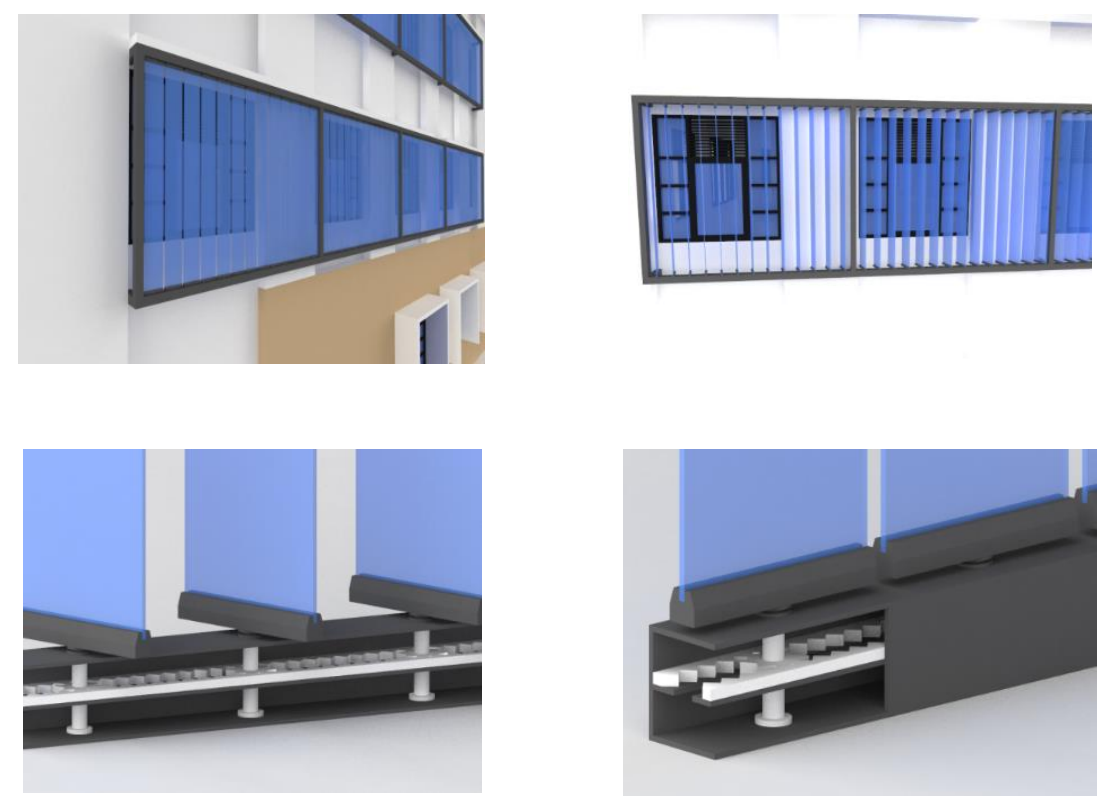

Figure 6. Details Double Skin Façade, 2015, Drawing. Source: Authors Figure 7 .

Simulation Results Data after the Application of Double Skin Facade is shown in Table 3 and 
Tabel 3. Daily Temperature Studio Image after Application of Double Skin Façade

\begin{tabular}{|c|c|c|c|}
\hline HOUR & INSIDE & OUTSIDE & TEMP.DIF \\
\hline & (C) & (C) & (C) \\
\hline 00.00 & 22,4 & 22 & 0,4 \\
\hline 01.00 & 22,1 & 21 & 1,1 \\
\hline 02.00 & 22,1 & 21 & 1,1 \\
\hline 03.00 & 21,8 & 20,1 & 1,7 \\
\hline 04.00 & 21,7 & 19,7 & 2 \\
\hline 05.00 & 21,5 & 19,2 & 2,3 \\
\hline 06.00 & 21,2 & 18 & 3,2 \\
\hline 07.00 & 22,9 & 17,4 & 5,5 \\
\hline 08.00 & 24,1 & 17,2 & 6,9 \\
\hline 09.00 & 24,5 & 18,4 & 6,1 \\
\hline 10.00 & 24,6 & 20,7 & 3,9 \\
\hline 11.00 & 24,9 & 23,7 & 1,2 \\
\hline 12.00 & 25,1 & 25,8 & $-0,7$ \\
\hline 13.00 & 24,9 & 27 & $-2,1$ \\
\hline 14.00 & 25,3 & 28 & $-2,7$ \\
\hline 15.00 & 26,1 & 28,6 & $-2,5$ \\
\hline 16.00 & 26,3 & 27,5 & $-1,2$ \\
\hline 17.00 & 25,7 & 27,4 & $-1,7$ \\
\hline 18.00 & 24,4 & 26 & $-1,6$ \\
\hline 19.00 & 23,9 & 24,6 & $-0,7$ \\
\hline 20.00 & 23,4 & 23,7 & $-0,3$ \\
\hline 21.00 & 23 & 23,2 & $-0,2$ \\
\hline 22.00 & 22,7 & 22,6 & 0,1 \\
\hline 23.00 & 22,6 & 22,5 & 0,1 \\
\hline
\end{tabular}

In table 3 the simulation results with the application of Double Skin Facade using Ecotect Analysis 2011 software, it can be seen that the results of the minus number at the diffuse temperature (difference) which is an indicator that the room is uncomfortable. As explained above, this uncomfortable temperature condition is because the temperature in the room is almost close to the temperature of the air outside the room. But on the results of this data, the number minus the diffuse (difference) the temperature in the room slightly decreased, meaning that the temperature in the room has decreased compared to when before using the Double Skin Facade. Although the results of this simulation still have a diffuse minus number, the temperature of the air inside the room is in the comfortable category. the average temperature in the room is $22.7^{\circ} \mathrm{C}$. 


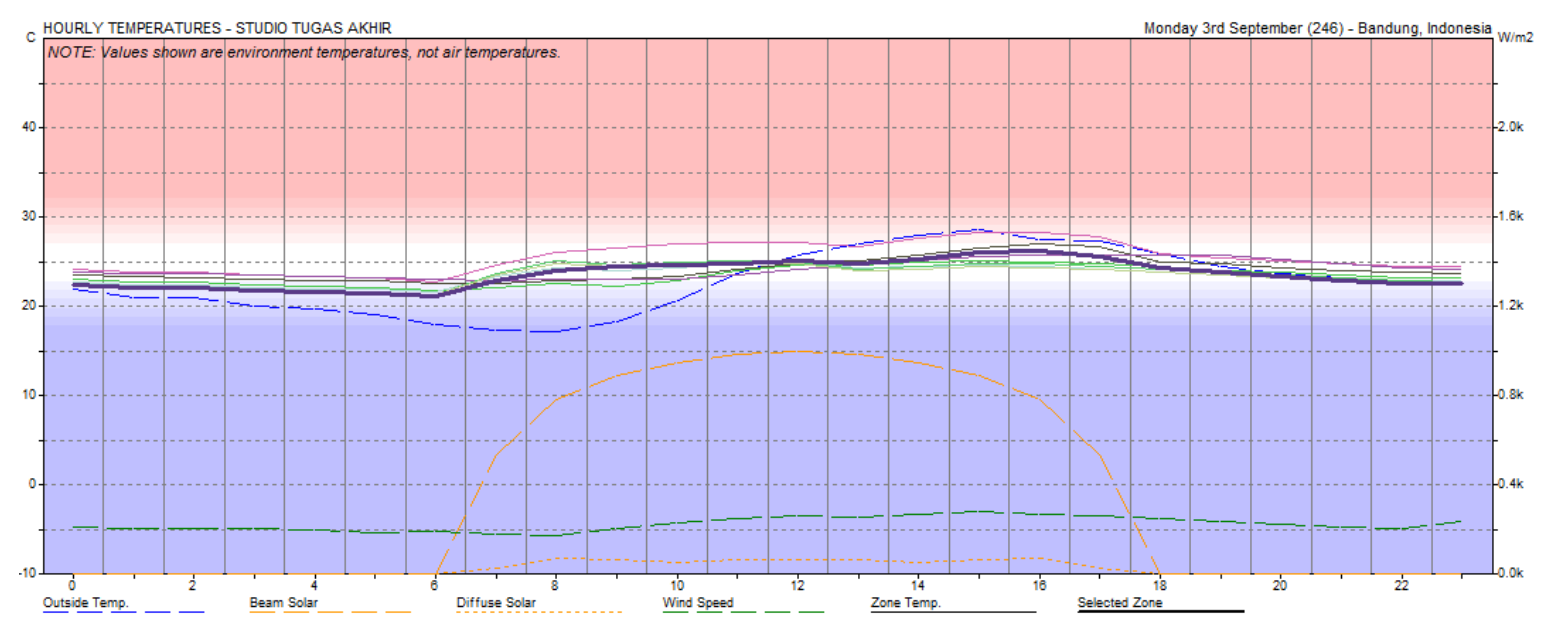

Figure 7. Daily Temperature Conditions of Image Studio Room After the application of DSF, 2015, Measurement. Source: Authors

In Figure 7 you can see the temperature of the Image Studio room at the time of measurement. This daily temperature is made to see at what time the room is comfortable and uncomfortable. In the figure, it can be seen that the graph of temperature increase has decreased. The green line in the picture is the Zone Temperature in the room. In the figure, the Temperature Zone line has decreased compared to before the application of Double Skin Facade, the line is below $25^{\circ} \mathrm{C}$. So, with the application of Double Skin Facade in this Image Studio room, it can reduce the heat radiation from the sun directly entering through the window. With Double Skin Facade, heat radiation will take longer to enter the room because it can be detained in advance in the double facade.

\section{Conclusion}

In general, air temperature data in the room with a high temperature of $27.2^{\circ} \mathrm{C}$ which occurred at $13.00-16.00$ is in the uncomfortable category, and the lowest temperature is around $23.6^{\circ} \mathrm{C}$ which occurs at $07.00-10.00$ is in the comfortable category. Humidity in the room generally ranges from $71.4 \%-76.5 \%$ which is in the uncomfortable category.

The use of Double Skin Facade based on simulation results using Ecotect Analysis can reduce air temperature and incoming solar radiation. With the application of Double Skin Facade in the Image Studio room, it can reduce the heat radiation from the sun directly entering through the window. So that it can create aspects of thermal comfort in the room.

\section{References}

Anonim. (1993). SNI T-14-1993-03: Standar Kenyamanan Termal. Jakarta: Puslitbang Departemen Pekerjaan Umum.

Anonim (2011). SNI 6197:2011, Konservasi Energi pada Sistem Pencahayaan. Jakarta: Badan Standar Nasional.

Anonim (2011). SNI 6390:2011, Konsetvasi Energi Sistem Tata Udara Bangunan Gedung. Jakarta: Badan Standar Nasional.

Cheol, Soo Park (2003). Occupant Responsive Optimal Control of Smart Façade Systems A Thesis Presented to The Academic Faculty, College of Architecture Georgia Institute of Technology.

Kragh, M. (2000). Building Envelopes and Environmental Systems. Paper presented at Modern Façades of Office Buildings Delft Technical University, the Netherlands. Retrieved from http://www.permasteelisa.com/upload/docs/pub_TUD02001.pdf.

Lechner, Norbert (2007). Heating, Cooling, Lighting: Metode Desain untuk Arsitektur Edisi Kedua. Jakarta: PT RajaGrafindo Persada.

Lippsmeier, G., (1997). Bangunan Tropis (Terjemahan, Syahmir). Jakarta, Erlangga.

Loncour, X., Deneyer, A., Blasco, M., Flamant, G., Wouters, P. (2004). Ventilated Double Facades Classification \& Illustration of Façade Concepts, Belgian Building Research Institute, 8 - 15, $17,28-29$.

Poirazis, H. \& Rosenfeld, J.L.J. (2004). Double Skin Façades for Office Building Division of Energy and Building Design Department of Construction and Architecture Lund Institute of Technology Lund University, 2004 Report EBD-R--04/3. Accessed date: 01 Mei 2012. 
Saelens, D. \& Hens, H. (2001). Experimental Evaluation of Naturally Ventilated Active Envelopes. International Journal of Thermal Envelopes and Building Science (Vol. 25, nr. 2, pp. 101127) Accessed date: 30 April 2012.

Satwiko, P. (2005). Fisika Bangunan 1, Yogyakarya: Andi.

Soegijanto. (1999). Bangunan di Indonesia dengan Iklim Tropis Lembab ditinjau dari Aspek Fisika Bangunan. Jakarta: Ditjen Dikti Depdikbud.

Sukmadinata, (2005), Metode Penelitian Pendidikan. Bandung: Remaja Rosdakarya.

Sugini. (2004). Pemaknaan Istilah - istilah Kualitas Kenyamanan Termal Ruang dalam Kaitan dengan Variabel Iklim Ruang. Jurnal Logika (Vol.1, No.2).

Sukawi. (2010). Kaitan Desain Selubung Bangunan terhadap Pemakaian Energi dalam Bangunan (Studi Kasus Perumahan Graha Padma Semarang). Jurnal Sains dan Teknologi (Vol. 1, No.1).

Talarosha, Basaria. (2005). Menciptakan Kenyamanan Termal dalam Bangunan. Jurnal SistemTeknik Industri (Vol. 6, No. 3).

Zanghirella, F., Perino, M., Serra, V. (2010). A Numerical Model to Evaluate The Thermal Behaviour of Active Transparent Facades. Elsevier Journal Energy and Buildings 43 (2011). Retrieved from www.elsevier.com/locate/enbuild. 1125, 1123-1138. 